\title{
Estimation of Soil Carbon Stocks of Urban Freshwater Wetlands in the Colombo Ramsar Wetland City and their Potential Role in Climate Change Mitigation
}

\author{
D.D.T.L. Dayathilake ${ }^{1}$ (D) $\cdot$ E. Lokupitiya ${ }^{1}$ - V.P.I.S. Wijeratne ${ }^{2}$
}

Received: 18 June 2020 / Accepted: 19 January 2021 / Published online: 24 February 2021

(C) The Author(s) 2021

\begin{abstract}
Wetlands hold significant potential for climate change mitigation due to their high capacity to sequester atmospheric carbon dioxide $\left(\mathrm{CO}_{2}\right)$. Colombo, Sri Lanka was recently declared as one of the eighteen global Ramsar wetland cities. The current study represents the first attempt to quantify soil organic carbon (SOC) stocks held by the urban freshwater wetlands in Colombo. The study focused on the extensive urban wetland ecosystems of Kolonnawa wetland and Thalawathugoda wetland park. SOC stocks were determined using three parameters: depth of soil, bulk density, and SOC concentration. Loss on ignition method was used in quantifying SOC concentrations. Average SOC stocks, up to a depth of $60 \mathrm{~cm}$ at Kolonnawa wetland and Thalawathugoda wetland park were estimated at $504 \pm 14 \mathrm{t} \mathrm{C/ha}$ and $550 \pm 23 \mathrm{tC} / \mathrm{ha}$, respectively. Furthermore, the total SOC stock at Kolonnawa wetland and Thalawathugoda wetland park were estimated at 198,408 $\pm 5564 \mathrm{t} \mathrm{CO}_{2}$ eq and 66,313 $\pm 2764 \mathrm{t} \mathrm{CO}_{2}$ eq, respectively. When considering global estimates, it was found that freshwater wetlands in Colombo hold a higher SOC stock than tropical wet forests and tropical dry forests. The current study highlights the importance of urban ecosystems in mitigating the ever increasing concentrations of atmospheric $\mathrm{CO}_{2}$.
\end{abstract}

Keywords Soil organic carbon stock $\cdot$ Tropical urban wetlands $\cdot$ Histosols

\section{Introduction}

The occurrence of climate change at an unprecedented scale is indicated by many studies and global assessments. Humaninduced warming reached approximately $1{ }^{\circ} \mathrm{C}$ above preindustrial levels in 2017, increasing at approximately $0.2^{\circ} \mathrm{C}$ per decade (Allen et al. 2018). Climate change mitigation has become critical as human induced changes continue to result in unpredictable consequences around the globe. The potential

D.D.T.L. Dayathilake

lushanyadayathilake@gmail.com

E. Lokupitiya

erandi@sci.cmb.ac.lk

V.P.I.S. Wijeratne

wijeratnesandamali@yahoo.com

1 Department of Zoology and Environment Sciences, University of Colombo, PO Box 1490, Colombo 03, Sri Lanka

2 Department of Geography, University of Colombo, Colombo 03, Sri Lanka to slow down climate change via the sequestration of carbon in soil has been investigated mostly during the past two decades, especially in the agricultural and forest ecosystems (Follett 2001; Lal 2004; Paustian et al. 1997; Lal 2008; Powlson et al. 2011).

The extent of world's wetlands is estimated to be about 5$8 \%$ of the total land surface of earth (Mitsch et al. 2013). Despite this low representation as a percentage of area on land, wetlands among all terrestrial ecosystems have the best capacity of any ecosystem to sequester and retain carbon through long term burial (Stern et al. 2007). Soils have a significant capacity to sequester carbon. Out of the total storage of carbon in earth's soils (i.e. $\sim 1400-2500 \mathrm{Pg} \mathrm{C} ; \mathrm{Pg}=10^{12} \mathrm{~kg}$ ) 20-30\% carbon is stored in wetlands ( $\mathrm{Lal} 2008$ ). In fact, global soil carbon sequestration rates of coastal wetlands $\left(210 \mathrm{~g} / \mathrm{cm}^{2} / \mathrm{yr}\right)$ and freshwater wetlands $\left(20-30 \mathrm{~g} / \mathrm{cm}^{2} / \mathrm{yr}\right)$ are higher than those of terrestrial forests $\left(10 \mathrm{~g} / \mathrm{cm}^{2} / \mathrm{yr}\right)$ (Chmura et al. 2003; Clark and York 2005).

Terrestrial plants remove $\mathrm{CO}_{2}$ from the atmosphere via photosynthetic uptake and some of this is rapidly released back by respiration. However, in wetlands much of this $\mathrm{CO}_{2}$ is incorporated into the organic carbon of the soil where its 
remineralization via microbial respiration is much slower. The longevity of this sink can vary from less than 10 years to many millions of years (Were et al. 2019). This long term terrestrial carbon accretion is thus associated with depressed microbial decomposition rates as a result of its anaerobic soil environment (Were et al. 2019). The diffusion of oxygen into these water saturated soils occurs thousand times more slowly in comparison to dry soils (Gorham 1991; Whiting and Chanton 2001). In addition, factors such as elevated water tables and high productivity underpin this capacity (Gorham1991).

A large proportion of carbon in wetlands is stored belowground as a result of accumulation of peat over centuries. However, the term 'peatland' is found to have no consistent definition throughout literature as a result of the use of different criteria by multiple studies. Soil organic carbon (SOC) concentration and thickness of the organic layer are two key criteria that are used in defining peat soil. One such definition by the United States Department of Agriculture (USDA) which classifies peat as histosols suggests the presence of an organic layer of at least $40 \mathrm{~cm}$ within the upper $50 \mathrm{~cm}$ of the soil surface containing more than $30 \%$ soil organic matter (SOM) (i.e. equivalent to $15 \%$ SOC concentration) (USDA 2014). On the other hand, Maltby and Immirzi (1993) suggests a minimum figure of 50\% SOM (equivalent to $25 \%$ SOC concentration) and $30 \mathrm{~cm}$ depth in defining peat soil. SOC concentration in soil, the most widely analyzed soil property of peat is documented to be around $50 \%$ in most cases (Tomlinson and Davidson 2000).

When considering carbon estimation in ecosystems, most existing studies have focused on dry-terrestrial ecosystems that span over large areas and have not taken into account the many small and scattered carbon-storing ecosystems such as mangroves and marshes. The amount of carbon sequestrated or released from tropical wetlands, particularly freshwater wetlands has been poorly quantified. As a consequence there is still uncertainty regarding the quantitative contribution of wetland ecosystems to the global carbon cycle (Chave et al. 2005).

Colombo, the commercial capital and the largest city of Sri Lanka, comprises a complex of manmade lakes, canals, marshes, paddy fields that are abandoned or currently in use. The Sri Lankan government has realized the ability to harness the capacity of the Colombo wetland complex to buffer urban communities against the adverse effects of climate change. This includes floods which are expected to increase in the future. Thus, the government has set up a comprehensive strategy to manage urban wetlands which include the establishment of wetland parks and the formulation of legal protection for urban wetlands. This strategy is considered as one of the first of its kind in the world and it will see the incorporation of wetlands into the city master plan. A report outlined in favour of this strategy, by the World Bank (WB) Climate
Change Group and the Global Facility for Disaster Reduction and Recovery (GFDRR) has recognized carbon storage as one of the co-benefits of the Colombo wetland complex (WB, GFDRR 2018).

However, these wetlands are under high anthropogenic pressure. A gross area reduction of $32 \%$ by 2002 compared to 1992 has occurred in the Kolonnawa wetland mainly owing to urbanization (IUCN, CEA 2006). This poses a wider threat as degraded and drained wetlands could result in significant losses of their stored carbon accumulated over millennia. The elevation of carbon emissions is primarily brought about by changes that affect wetland hydrology as the draining wetlands decrease $\mathrm{CO}_{2}$ accretion and increase the rates of microbial decomposition leading to higher rates of $\mathrm{CO}_{2}$ emissions to the atmosphere (Miettinen et al. 2017).

The primary objective of this study was to estimate the SOC stocks of the two main freshwater wetlands, the Kolonnawa wetland and the Thalawathugoda wetland park, located within the Colombo wetland complex. Secondarily, the study aimed to establish a comparison among SOC stocks of various ecosystems to better assess the relative potential of freshwater wetlands to store carbon. In addition, the presence of peat soil at the two study sites was validated upon SOC concentrations and thickness of the organic layer. This study is an attempt to fill in the existing knowledge gap/s on urban freshwater ecosystems. It would essentially contribute to the body of knowledge on the potential of tropical freshwater wetlands to act as regulators of global climate by influencing the carbon cycle via carbon sequestration.

\section{Material and Methods}

\section{Study Sites}

The monitored sites, the Kolonnawa wetland and the Thalawathugoda wetland park are distributed within the Colombo city, the commercial capital of Sri Lanka. The location of the Colombo city is shown in Fig. 1. Colombo city was declared as a Ramsar wetland city in 2018 at the 13th Conference of the Parties to the Ramsar Convention on Wetlands. According to the Ramsar wetland classification, both the Kolonnawa wetland and the Thalawathugoda wetland park are classified as forested peatlands (MCUDP 2016). Figure 2 shows a map of the two study sites. The total extents of the Kolonnawa wetland and the Thalawathugoda wetland park are 107.28 ha and 32.87 ha, respectively. Most parts of both wetlands are currently dominated by Annona glabra, an invasive alien species (Hettiarachchi et al. 2014). Annona glabra spreads across urban freshwater wetlands of Sri Lanka, particularly in the Western Province, forming mono-carpets of the single species (MCUDP 2016). 
Fig. 1 Map showing the location of Colombo, the commercial capital of Sri Lanka $79^{\circ} 30^{\prime} 0 "$ E $80^{\circ} 0^{\prime} 0^{\prime \prime}$ E $80^{\circ} 30^{\prime} 0^{\prime \prime}$ E $81^{\circ} 0^{\prime} 0^{\prime \prime}$ E $81^{\circ} 30^{\prime} 0^{\prime \prime}$ E $82^{\circ} 0^{\prime} 0^{\prime \prime}$ E

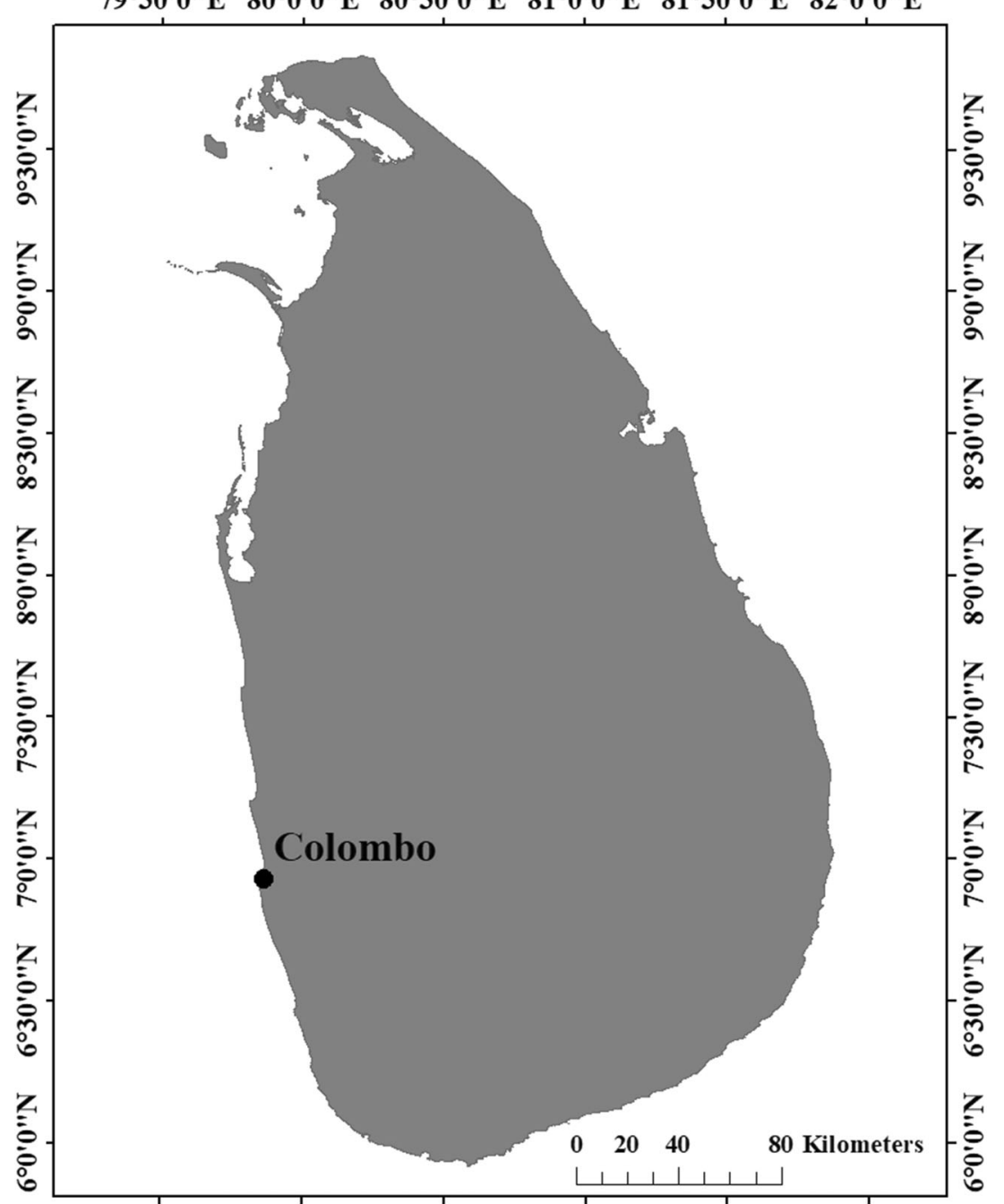

$79^{\circ} 30^{\prime} 0^{\prime \prime}$ E $80^{\circ} 0^{\prime} 0^{\prime \prime}$ E $80^{\circ} 30^{\prime} 0^{\prime \prime}$ E $81^{\circ} 0^{\prime} 0^{\prime \prime}$ E $81^{\circ} 30^{\prime} 0^{\prime \prime}$ E $82^{\circ} 0^{\prime} 0^{\prime \prime}$ E
Sri Lanka is located within the tropics, i.e., between $5^{\circ} 55^{\prime}$ to $9^{\circ} 51^{\prime}$ North latitude and $79^{\circ} 42^{\prime}$ to $81^{\circ} 53^{\prime}$ East longitude. Three major climatic zones could be found in this tropical island as the central hills divide the country by acting as a barrier to the monsoon winds. The study sites lie within the wet zone of Sri Lanka and receive a mean annual rainfall of IUCN, $2006 \mathrm{~mm}$ and the average annual temperature ranges between $25^{\circ} \mathrm{C}$ and $27^{\circ} \mathrm{C}$ (IUCN, CEA 2006). Soil pH of the Kolonnawa wetland ranges between 3.5 and 4.0 and that of the Thalawathugoda wetland park ranges between 3.4 and 4.1 (MCUDP 2016).

The hydrology of the two wetlands differs only in a few aspects. Both wetlands undergo seasonal flooding during monsoon periods. Accordingly, the surface water levels reach a peak hydro period during the months of May and November. These freshwater wetlands depend on rainfall and surface water supplied through the wider wetland complex within the Colombo Metropolitan Region.

\section{Field Sampling}

Field sampling was conducted from July to October 2018. Random sampling points were generated using the ArcGIS software. The number of sampling plots was determined statistically in order to reach a desired precision level of less than $15 \%$ of the true value of the mean SOC stock at the $95 \%$ confidence level. Three types of soil variables were measured: (1) depth, (2) bulk density, and (3) SOC concentration. A $60 \mathrm{~cm}$ long soil auger of diameter $2 \mathrm{~cm}$ was used in obtaining soil core samples for quantifying SOC concentrations. A metal tube of diameter $5.5 \mathrm{~cm}$ and core height $21 \mathrm{~cm}$ was used in obtaining soil core samples for bulk density estimations. Sampling locations were recorded using GPS coordinates obtained from the eXplorist510 GPS device.

Two sets of cores were collected at each sampling plot 1) a set of nine core samples for the analysis of SOC concentration and 2) a set of three core samples for bulk density. Soil cores for determining SOC concentrations were taken at three 


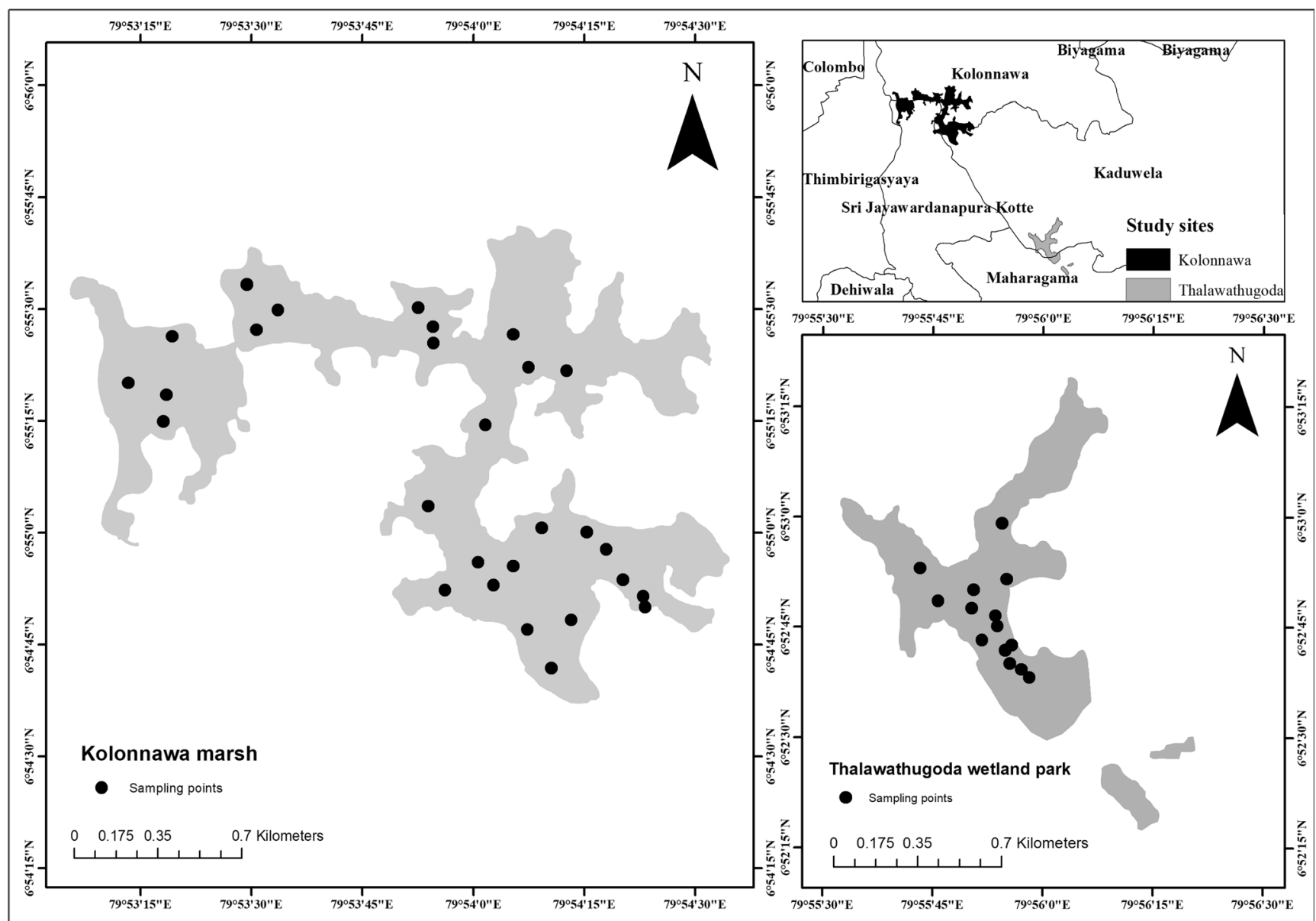

Fig. 2 Map of study sites, Kolonnawa wetland and Thalawathugodawetland park. Solid black circles represent points of sampling. The inset in the upper right shows the location of the study area within a section of the Colombo Ramsar wetland city consecutive depth intervals up to a constant depth of $60 \mathrm{~cm}$ starting from the surface layer immediately below the litter layer (i.e., from the surface to a depth of $20 \mathrm{~cm}, 20-40 \mathrm{~cm}$, and 40-60 cm). Three such cores, each consisting of samples from three depth intervals, were collected at each sampling plot. This made up a total of 9 samples per each sampling plot for the analysis of SOC concentration. Following this, soil core samples from corresponding soil depth intervals at each sampling plot were pooled together into one sample to form a composite sample (Bernal and Mitsch 2012). Accordingly, three composite samples were transferred to the laboratory from each sampling plot for the analysis of SOC concentration. An additional set of cores; one each at 0-20 cm, 20$40 \mathrm{~cm}$ and 40-60 $\mathrm{cm}$ were obtained at each sampling plot for the determination of bulk density. Care was taken to avoid any loss of soil from the cores.

\section{Laboratory Analysis for Determining Soil Organic Carbon Concentration and Bulk Density}

One hundred and twenty six composite samples in total were analyzed in the laboratory for SOC concentration while forty- two samples were analyzed for bulk density. SOM concentration was determined using the technique of loss on ignition (LOI). LOI is preferred over the wet chemical oxidation protocol for its fairly high accuracy, simplicity, and convenience in the case of large sample sizes (Hoogsteen et al. 2015).

In the laboratory each sample was air dried for about a week until there was no apparent moisture. Dry samples were then ground to pass through a $2 \mathrm{~mm}$ particle size mesh and homogenized. A sample mass of $5.00 \mathrm{~g} \pm 0.1 \mathrm{~g}$ was then placed in $30 \mathrm{ml}$ crucibles that were preheated at $90^{\circ} \mathrm{C}$, cooled, and then pre-weighed. Samples were tested for carbonates by treating with $6 \mathrm{~N} \mathrm{HCl}$ and by observing for effervescence (Craft et al. 1991). Pre-prepared samples were oven-dried at $90{ }^{\circ} \mathrm{C}$ for $24 \mathrm{~h}$ (Landva et al. 1983) and then subjected to ignition at $550{ }^{\circ} \mathrm{C}$ for $4 \mathrm{~h}$ in the muffle furnace (Howard and Howard 1990). Following this the samples were cooled to room temperature in a desiccator over silica gel and weighed (Bernal and Mitsch 2012). In the case of bulk density determination samples were first air dried in the laboratory for a minimum of 5 days and then oven dried at $105^{\circ} \mathrm{C}$ for $48 \mathrm{~h}$, cooled to room temperature in a desiccator over silica gel, and weighed (Kauffman and Donato 2012). 


\section{Data Analysis}

Concentration of SOM in samples was determined using eq. 1 (Kauffman and Donato 2012).

SOM $\%=\frac{\text { weight }_{90^{\circ} \mathrm{C}}(\mathrm{g})-\text { weight }_{550^{\circ} \mathrm{C}}(\mathrm{g})}{\text { weight }_{90^{\circ} \mathrm{C}}(\mathrm{g})} \times 100$
The SOC concentration was then obtained by multiplying the SOM concentration by a factor of 0.5 (Pribyl 2010). SOC stock per each sampled depth, per area was obtained by multiplying the SOC concentration by both the bulk density and soil depth as shown by Eq. 2 .

$C(t / h a)=\left[\left(\right.\right.$ soil bulk density $\left.\left(\mathrm{g} / \mathrm{cm}^{3}\right)\right) \times \operatorname{soil}$ depth $(\mathrm{cm}) \times$ SOC concentration $\left.)\right] \times 100$

Mean SOC stock, per hectare, and per depth of soil was determined by averaging the SOC stock ( $\mathrm{t} \mathrm{C} / \mathrm{ha}$ ) across all plots. Results thus obtained were extrapolated to the total area of the study site to obtain the SOC stock per depth. The total SOC stock of the wetland was determined by combining the resultant values of all three depth intervals. The $\mathrm{CO}_{2}$ eq of the total carbon stock was obtained by multiplying the carbon stock by 3.67 (Kauffman and Donato 2012).

Calculations were performed on the Minitab 18 statistical software. The statistical significance in the difference of SOC concentrations and bulk density values between the two wetlands was determined using two sample t-tests at 5\% level of significance. In addition, one-way ANOVA was used to analyze for any statistical significance in mean SOC concentrations as well as mean bulk density values along the different studied depths at the Kolonnawa wetland and the Thalawathugoda wetland park.

\section{Results}

\section{Soil Organic Carbon Concentration}

Mean SOC concentrations at the two wetlands are presented below. Mean SOC concentrations at the three consecutive depth intervals, $0-20 \mathrm{~cm}, 20-40 \mathrm{~cm}$ and $40-60 \mathrm{~cm}$ of the Kolonnawa wetland were $20.95 \pm 1.28 \%, 18.79 \pm 1.36 \%$ and $17.50 \pm 1.29 \%$, respectively. Mean SOC concentrations at the three consecutive depth intervals, $0-20 \mathrm{~cm}, 20-40 \mathrm{~cm}$ and 40 $60 \mathrm{~cm}$ of the Thalawathugoda wetland park were $10.75 \pm$ $0.92 \%, 10.54 \pm 0.93 \%$ and $11.11 \pm 0.79 \%$, respectively. Taken together, the results of the t-tests performed for the comparison of SOC concentrations between corresponding depth intervals of the two wetlands indicated that there existed a statistically significant difference in mean SOC concentrations between the Kolonnawa wetland and the Thalawathugoda wetland park, across all considered depths $(0-20 \mathrm{~cm} ; p<0.001$, $20-40 \mathrm{~cm} ; p<0.001$ and $40-60 \mathrm{~cm} ; p<0.001)$. However, there was no statistically significant difference in mean SOC concentrations between the different studied depths of the
Kolonnawa wetland as determined by one-way ANOVA, F $(2,78)=1.77, p=0.177$. Similarly, there was no statistically significant difference in mean SOC concentrations between the different studied depths of the Thalawathugoda wetland park as determined by one-way ANOVA, F $(2,33)=0.11$, $p=0.900$. A graphical representation of the medians and level of variability of SOC concentration at the Kolonnawa wetland and the Thalawathugoda wetland park is shown in Fig. 3.

\section{Soil Bulk Density}

Soil bulk density was found to be higher, in all depth intervals, at the Thalawathugoda wetland park in comparison to the Kolonnawa wetland. Taken together, observed bulk densities ranged between $0.17-1.12 \mathrm{~g} / \mathrm{cm}^{3}$ and $0.51-1.40 \mathrm{~g} / \mathrm{cm}^{3}$ at the Kolonnawa wetland and the Thalawathugoda wetland park, respectively. Mean bulk densities at the two wetlands are presented below. Estimated bulk densities at the three consecutive depth intervals, $0-20 \mathrm{~cm}, 20-40 \mathrm{~cm}$ and $40-60 \mathrm{~cm}$ of the Kolonnawa wetland were $0.47 \pm 0.04 \mathrm{~g} / \mathrm{cm}^{3}, 0.51 \pm 0.04 \mathrm{~g} / \mathrm{cm}^{3}$ and $0.49 \pm$ $0.04 \mathrm{~g} / \mathrm{cm}^{3}$, respectively. Estimated bulk densities at the three consecutive depth intervals, $0-20 \mathrm{~cm}, 20-40 \mathrm{~cm}$ and $40-60 \mathrm{~cm}$ of the Thalawathugoda wetland park were $0.85 \pm 0.07 \mathrm{~g} / \mathrm{cm}^{3}$,

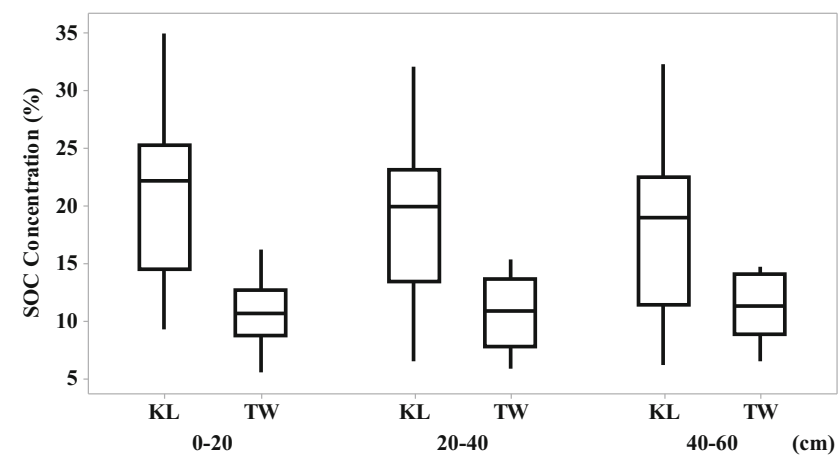

KL - Kolonnawa wetland

TW - Thalawathugoda wetland park

Fig. 3 Level of variation of SOC concentration - soil organic carbon concentration at the Kolonnawa wetland (KL) and the Thalawathugoda wetland park (TW) along three depth intervals of soil starting from the surface layer up to a depth of $60 \mathrm{~cm}$ 
$0.89 \pm 0.07 \mathrm{~g} / \mathrm{cm}^{3}$ and $0.90 \pm 0.06 \mathrm{~g} / \mathrm{cm}^{3}$, respectively. The results of the two sample t-tests indicated a statistically significant difference in mean bulk densities in corresponding depth intervals between the Kolonnawa wetland and the Thalawathugoda wetland park $(0-20 \mathrm{~cm} ; p<0.001,20-40 \mathrm{~cm} ; p<0.001=0.000$ and $40-60 \mathrm{~cm} ; p<0.001)$. However, as in the case of SOC concentrations, there was no statistically significant difference in mean bulk density values between the different studied depths of the Kolonnawa wetland as determined by a one-way ANOVA, F $(2,78)=0.22, p=0.805$. Similarly, there was no statistically significant difference in mean bulk density values between the different studied depths of the Thalawathugoda wetland park as determined by a one-way ANOVA, $\mathrm{F}(2,33)=0.18$, $p=0.834$. Figure 4 shows a graphical representation of the medians and level of variability of bulk densities at the Kolonnawa wetland and the Thalawathugoda wetland park.

\section{Total Soil Organic Carbon Stock}

Table 1 presents a summary of SOC stocks across different depth intervals at the two wetlands. The total SOC stock at the Kolonnawa wetland and the Thalawathgoda wetland park were estimated at $198,408 \pm 5564 \mathrm{t} \mathrm{CO}_{2}$ eq and $66,313 \pm$ $2764 \mathrm{t} \mathrm{CO}_{2}$ eq, respectively. A general trend observed with respect to the SOC stocks at the Kolonnawa wetland was decreasing SOC stock with increasing depth. On the contrary, SOC stocks at the Thalawathgoda wetland park showed an increasing trend with increasing depth: the highest SOC stock was found in the deepest layer $(40-60 \mathrm{~cm})$.

Furthermore, it is interesting to note that the bottommost layers (40-60 cm soil layer) at both the Kolonnawa wetland and the Thalawathugoda wetland Park contain significantly high carbon stocks (Kolonnawa wetland $-156.37 \pm 8.60$ and Thalawathugoda wetland Park $-196.39 \pm 15.30 \%)$ and high carbon concentrations (Kolonnawa wetland $-17.50 \pm 1.29 \%$ and Thalawathugoda wetland Park $-11.11 \pm 0.79 \%)$. This

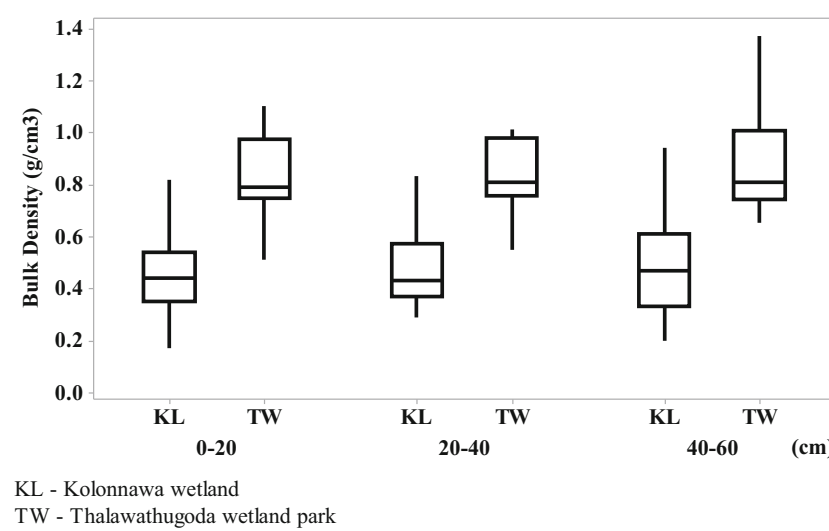

Fig. 4 Level of variation of bulk density at the Kolonnawa wetland (KL) and the Thalawathugoda wetland park (TW) along three depth intervals of soil starting from the surface layer up to a depth of $60 \mathrm{~cm}$ indicates the high probability of deeper soil layers retaining significant SOC stocks.

\section{Discussion}

This study seeks to present an estimate of the total SOC stock of the Kolonnawa wetland and Thalawathugoda wetland park, both of which are part of the wider wetland complex distributed within the Colombo Ramsar wetland city of Sri Lanka. It is important to establish a comparison among SOC stocks of various regional wetlands as well as other local wetlands such as mangrove wetlands to better assess the relative potential of these freshwater wetlands to retain carbon. In doing so, the results obtained by the current study were limited to the upper $40 \mathrm{~cm}$ or in some cases to the upper $20 \mathrm{~cm}$ of soil in order to limit comparisons to those depths previous studies have considered. Table 2 provides a comparison of the soil carbon stocks of certain previous studies against the carbon stocks estimated in the present study. It was found that freshwater wetlands studied in the current research hold a SOC stock of $347.56 \pm 12 \mathrm{t} \mathrm{C} / \mathrm{ha}$ in the upper $40 \mathrm{~cm}$ at the Kolonnawa wetland and a stock of $353.32 \pm 17 \mathrm{t} \mathrm{C/ha} \mathrm{in} \mathrm{the} \mathrm{upper} 40 \mathrm{~cm}$ at the Thalawathugoda wetland park, both of which are comparable to stocks held by mangrove soils of Sri Lanka (Perera and Amarasinghe 2019). Both study sites store higher SOC stocks compared to deep freshwater marshes, shallow freshwater marshes and permanent open freshwater wetlands of the extensive series of South Eastern wetlands in Australia (Paul et al. 2018). In addition, the SOC stocks of the freshwater wetlands of the current study were higher compared to Palustrine wetlands concentrated in Northeast China and the Qinghai-Tibet Plateau (Ma et al. 2015). Furthermore, a comparison among estimated SOC stocks of freshwater wetlands and other ecosystems was established to better understand the relative potential of freshwater wetlands as carbon sinks. In a comparison with reference figures reported by IPCC, the results of the current study showed that these freshwater wetlands (Kolonnawa wetland $-179.38 \pm 8.67 \mathrm{t} \mathrm{C} / \mathrm{ha}$, upper $20 \mathrm{~cm}$ and Thalawathgoda wetland park $-172.88 \pm 11.50 \mathrm{t}$ C/ha, upper $20 \mathrm{~cm}$ ) retain higher SOC stocks than tropical wet forests (44-66 t C/ha, upper $30 \mathrm{~cm}$ ) and tropical dry forests (31-38 t C/ha, upper $30 \mathrm{~cm}$ ) (IPCC 2003).

\section{Soil Organic Carbon Concentration}

Kolonnawa wetland holds a significantly higher average percentage of SOC concentration $(21 \%$ in upper $0-20 \mathrm{~cm}$, $\sim 19 \%$ at a depth of $20-40 \mathrm{~cm}$ and $\sim 18 \%$ at a depth of 40 $60 \mathrm{~cm}$ ) in comparison to the Thalawathugoda wetland park ( $\sim 11 \%$ at all depth intervals; $0-20 \mathrm{~cm}, 20-40 \mathrm{~cm}$ and 40 $60 \mathrm{~cm}$ ). Presence of standing water for prolonged periods at the Kolonnnawa wetland is likely to have retarded oxidation 
Table 1 Summary of the mean soil organic carbon stock ( $\mathrm{t} C /$ ha), total soil organic carbon stock per depth ( $\mathrm{t} \mathrm{C}$ ) and total ecosystem soil organic carbon stock ( $(\mathrm{C})$ at the Kolonnawa wetland and the Thalawathugoda wetland park across three soil depth intervals $(\mathrm{cm})$

\begin{tabular}{|c|c|c|c|c|c|}
\hline & $\begin{array}{l}\text { Depth } \\
\text { interval }(\mathrm{cm})\end{array}$ & $\begin{array}{l}\text { Mean soil organic } \\
\text { carbon per hectare (t C/ha) }\end{array}$ & $\begin{array}{l}\text { Total soil organic carbon } \\
\text { per hectare }(\mathrm{t} \mathrm{C} / \mathrm{ha})\end{array}$ & $\begin{array}{l}\text { Total layer soil organic } \\
\text { carbon stock }(\mathrm{t} C)\end{array}$ & $\begin{array}{l}\text { Total soil organic } \\
\text { carbon }(\mathrm{t} C)\end{array}$ \\
\hline \multirow[t]{4}{*}{ Kolonnawa wetland ${ }^{\text {a }}$} & $0-20$ & $179.38 \pm 8.67$ & & $19,244 \pm 930.11$ & \\
\hline & $20-40$ & $168.18 \pm 7.12$ & & $18,042 \pm 763.83$ & \\
\hline & $40-60$ & $156.37 \pm 8.60$ & & $16,776 \pm 922.61$ & \\
\hline & & & $504 \pm 14$ & & $54,062 \pm 1516$ \\
\hline \multirow{4}{*}{$\begin{array}{l}\text { Thalawathugoda } \\
\text { wetland park }^{\mathrm{b}}\end{array}$} & $0-20$ & $172.88 \pm 11.50$ & & $5683 \pm 378.01$ & \\
\hline & $20-40$ & $180.44 \pm 12.60$ & & $5931 \pm 414.16$ & \\
\hline & $40-60$ & $196.39 \pm 15.30$ & & $6455 \pm 502.91$ & \\
\hline & & & $550 \pm 23$ & & $18,069 \pm 753$ \\
\hline
\end{tabular}

${ }^{\mathrm{a}}$ The total extent of area of the Kolonnawa wetland -107.28 ha

${ }^{\mathrm{b}}$ The total extent of area of the Thalawathugoda wetland park -32.87 ha

of SOM leading to higher accretion rates of SOC either via resultant anaerobic conditions in the soil or lower soil temperature with respect to the immediate temperature of the environment, or the combination of both conditions (Saunders et al. 2007). Higher SOC concentrations at the Kolonnawa wetland, as shown by the present study, could also be attributed to the dominance of Annona glabra, an invasive alien species which according to Mielke et al. (2005) and Zotz et al. (1997) develops a massive atypical root system in anoxic soils. Such extensive root syetems could potentially enhance the organic carbon stock, particularly in soil sediments by trapping the particulate and organic matter brought in by adjescent ecosystems during frequent inundation (Sebastian and Chacko 2006).

The average SOC concentration at the Kolonnawa wetland $(20.95 \pm 1.28 \%-17.50 \pm 1.29 \%)$ is well above the minimum threshold established by the USDA for peat soils - i.e., the presence of an organic layer of at least $40 \mathrm{~cm}$ within the upper $50 \mathrm{~cm}$ of the soil surface containing more than $30 \% \mathrm{SOM}$, i.e. equivalent to $15 \%$ SOC concentration, assuming $50 \%$ of SOM is carbon. However, peat reservoirs could impart a negative effect on the overall carbon cycle if subjected to mismanagement, primarily as a result of land use changes. This appears to be threatening in the light of findings reported by Hettiarachchi et al. (2014) which reports of a $60 \%$ reduction of the wetland area at Kolonnawa since 1980. Thus, it is essential that all concerned authorities take necessary steps to conserve existing peatlands. On the other hand, the Thalawathugoda wetland park was found to contain much lower SOC concentrations. The park has undergone various soil additions in the recent past. Thus, it is likely that it has not been long enough for top layers to accumulate organic matter. According to Lucas (1982), generally requires between 600 and 2400 years for the accumulation of $1 \mathrm{~m}$ of peat with an average of 1500 years.

\section{The Potential Role in Climate Change Mitigation}

Multilateral agreements such as the UNFCCC (UNFCCC 2017) and the Ramsar Convention on Wetlands (STRP 2009) have increasingly recognized climate regulation as one of the key services provided by wetlands. Further, the Millennium Ecosystem Assessment (2005) also recognizes their capacity to underpin climate adaptation and resilience. The Paris Agreement in 2015 (UNFCCC 2017) set an ambitious goal of keeping the increase in global average temperature to well below $2{ }^{\circ} \mathrm{C}$ above the pre-industrial levels while pursuing efforts to limit the increase to $1.5^{\circ} \mathrm{C}$. IPCC (2002) defined mitigation as an anthropogenic intervention to reduce net greenhouse gas (GHG) emissions that would lessen the pressure on natural and human systems from climate change. Some of the key mitigation options recommended by IPCC (2002) include the reduction of land-based emissions via conservation of existing large pools in ecosystems and the increase in the rate of carbon sequestration by ecosystems. On the one hand, wetlands (including peatlands) are recognized as the largest natural terrestrial carbon sink; the area considered as near natural peatland sequesters 0.37 gigatonnes of $\mathrm{CO}_{2}$ per annum. This is higher than the aggregate amount of carbon stored by all other vegetation types and it is interesting to note that the majority of these pools are in Southeast Asia. On the other hand, degraded peatlands act as major sources of GHG emissions, releasing roughly $6 \%$ of all global anthropogenic $\mathrm{CO}_{2}$ emissions per annum (IUCN 2017). In fact, land use changes causing abrupt and significant changes in wetlands soil could potentially switch these long-term carbon sinks to sources of carbon to the atmosphere (Joosten et al. 2016). In this context, managing soil organic carbon stocks in tropical wetlands should be given a high priority; more than $80 \%$ of carbon in these ecosystems is stored belowground, particularly as SOC (Murdiyarso et al. 2013). 
Table 2 Soil organic carbon stocks (t C/ha) of the current study vs. average soil organic carbon stocks ( $\mathrm{t}$ C/ha) observed in some previous studies

\begin{tabular}{|c|c|c|c|c|}
\hline Wetland Type & Study site/Country & $\begin{array}{l}\text { Average carbon } \\
\text { stock }(\mathrm{t} \mathrm{C} / \mathrm{ha}) \pm \mathrm{SD}\end{array}$ & $\begin{array}{l}\text { Average depth } \\
\text { examined }(\mathrm{cm}) \pm \mathrm{SD}\end{array}$ & References \\
\hline Deep freshwater marsh & State of Victoria, southeastern Australia & $230 \pm 190$ & $72 \pm 29$ & Paul et al. 2018 \\
\hline $\begin{array}{l}\text { Permanent open } \\
\text { freshwater }\end{array}$ & State of Victoria, southeastern Australia & $110 \pm 120$ & $62 \pm 21$ & Paul et al. 2018 \\
\hline $\begin{array}{l}\text { Shallow freshwater } \\
\text { marsh }\end{array}$ & State of Victoria, southeastern Australia & $200 \pm 200$ & $61 \pm 23$ & Paul et al. 2018 \\
\hline Mangroves & Negombo, wet zone, Sri Lanka & $406.01 \pm 34.96$ & 45 & $\begin{array}{l}\text { Perera and } \\
\text { Amarasinghe } \\
2019\end{array}$ \\
\hline Mangroves & Chilaw, intermediate zone, Sri Lanka & $346.83 \pm 5.45$ & 45 & $\begin{array}{l}\text { Perera and } \\
\text { Amarasinghe } \\
2019\end{array}$ \\
\hline Mangroves & Batticaloa, dry zone, Sri Lanka & $316.29 \pm 33.80$ & 45 & $\begin{array}{l}\text { Perera and } \\
\text { Amarasinghe } \\
2019\end{array}$ \\
\hline Mangroves & $\begin{array}{l}\text { Hualaxtoc, Sian Ka'an Biosphere Reserve (SKBR) in the } \\
\text { Yucatan Peninsula, Mexico }\end{array}$ & $418 \pm 48.94$ & 50 & $\begin{array}{l}\text { Adame et al. } \\
2013\end{array}$ \\
\hline Marsh & $\begin{array}{l}\text { Punta Gorda, Sian Ka'an Biosphere Reserve (SKBR) in the } \\
\text { Yucatan Peninsula, Mexico }\end{array}$ & $118 \pm 6.48$ & 50 & $\begin{array}{l}\text { Adame et al. } \\
2013\end{array}$ \\
\hline $\begin{array}{l}\text { Peatland according to } \\
\text { USDA definition }\end{array}$ & $\begin{array}{l}\text { Average global wetland soil carbon pool; Corresponding to } \\
\text { total histosols soil carbon pool } 41.5 \mathrm{Gt} \mathrm{C}\end{array}$ & 375 & 33 & Buringh 1984 \\
\hline Palustrine wetlands & $\begin{array}{l}\text { China; concentrated in Northeast China (49\%) and the } \\
\text { Qinghai-Tibet Plateau (41\%) }\end{array}$ & $311.7 \pm 105.5$ & 100 & Ma et al. 2015 \\
\hline \multicolumn{5}{|l|}{ Current study } \\
\hline Forested peatland & Kolonnawa wetland & $347.56 \pm 12$ & 40 & \\
\hline Forested peatland & Kolonnawa wetland & $504 \pm 14$ & 60 & \\
\hline Forested peatland & Thalawathugoda wetland park & $353.32 \pm 17$ & 40 & \\
\hline Forested peatland & Thalawathugoda wetland park & $550 \pm 23$ & 60 & \\
\hline
\end{tabular}

Given their significant vulnerability to loss via land use change, especially in urban areas, it is timely to include these urban ecosystems in climate change mitigation options. In addition, given the shrinking forest cover and mangrove habitats in the tropics, urban wetlands could be thought of as a viable solution we could resort to in terms of optimizing and enhancing the ecosystem-level carbon sequestration.

Further research should be carried out on the annual stock change estimates of mangrove as well as freshwater wetlands as they could potentially produce an idea of the amount of carbon emissions that could be offset by these ecosystems per annum. Carbon stock estimation of wetlands is highly encouraged as it has become a perquisite for developing national climate change mitigation strategies.

\section{Conclusions}

The current study provides evidence for the high carbon storage potential of urban freshwater wetlands. As concluding remarks, it is important to point out that this study does not propose urban wetlands as the sole viable solution for climate change mitigation but rather proposes urban wetlands as a highly important ecological component that complements the net carbon sink. Furthermore, the study points out that small and scattered urban wetlands contribute considerably to the overall carbon budget despite the lack of attention paid on these ecosystems. The two tropical freshwater wetland ecosystems considered in the current study showed much higher SOC stocks compared to the values provided in the IPCC (2003) for tropical forests and Paul et al. (2018) for similar ecosystems.

Supplementary Information The online version contains supplementary material available at https://doi.org/10.1007/s13157-021-01424-7.

Acknowledgements The authors wish to thank the academic staff of the Department of Zoology and Environment Sciences of the Faculty of Science, University of Colombo and the officials of the Sri Lanka Land Reclamation and Development Corporation including Ms. Chethika Gunasiri for their support. In addition we thank the participants of this project for their contributions towards data collection in the field. This 
research was conducted under the funds from University of Colombo, Sri Lanka for student research.

Authors' Contributions We state that all authors contributed significantly to the development of this manuscript. DDTLD conducted the field study and analyses under the supervision of EL, and took the lead in preparing the manuscript with the input from all the authors. VPISW conducted the spatial analysis and was also involved in designing the study.

Funding This research was funded by the University of Colombo, Sri Lanka.

Data Availability The datasets supporting the conclusions of this article are included as additional files.

Code Availability Not applicable.

\section{Declarations}

Ethics Approval Not applicable.

Consent to Participate Not applicable.

Consent for Publication Not applicable.

Conflict of Interest There are no conflicts of interest to disclose.

Open Access This article is licensed under a Creative Commons Attribution 4.0 International License, which permits use, sharing, adaptation, distribution and reproduction in any medium or format, as long as you give appropriate credit to the original author(s) and the source, provide a link to the Creative Commons licence, and indicate if changes were made. The images or other third party material in this article are included in the article's Creative Commons licence, unless indicated otherwise in a credit line to the material. If material is not included in the article's Creative Commons licence and your intended use is not permitted by statutory regulation or exceeds the permitted use, you will need to obtain permission directly from the copyright holder. To view a copy of this licence, visit http://creativecommons.org/licenses/by/4.0/.

\section{References}

Adame F, Kauffman JB, Medina I, Gamboa JN, Torres O, Caamal-Sosa JP, Reza M, Silveira JH (2013) Carbon stocks of tropical coastal wetlands within the Karstic landscape of the Mexican Caribbean. PLoS One 8:e56569. https://doi.org/10.1371/journal.pone.0056569

Allen MR, Dube OP, Solecki W, Aragón-Durand F, Cramer W, Humphreys S, Kainuma M, Kala J, Mahowald N, Mulugetta Y, Perez R, Wairiu M, Zickfeld K (2018) Framing and context. In: Masson-Delmotte V, Zhai P, Pörtner H-O, Roberts D, Skea J, Shukla PR, Pirani A, Moufouma-Okia W, Péan C, Pidcock R, Connors S, Matthews JBR, Chen Y, Zhou X, Gomis MI, Lonnoy E, Maycock T, Tignor M, Waterfield T (eds) Global warming of $1.5^{\circ} \mathrm{C}$. an IPCC special report on the impacts of global warming of $1.5^{\circ} \mathrm{C}$ above pre-industrial levels and related global greenhouse gas emission pathways, in the context of strengthening the global response to the threat of climate change, sustainable development, and efforts to eradicate poverty. https://www.ipcc.ch/site/assets/
uploads/sites/2/2019/06/SR15_Full_Report_Low_Res.pdf2019/06/ SR15_Full_Report_Low_Res.pdf

Bernal B, Mitsch WJ (2012) Comparing carbon sequestration in temperate freshwater wetland communities. Global Change Biology 18: 1636-1647. https://doi.org/10.1111/j.1365-2486.2011.02619.x

Buringh P (1984) Organic carbon in soils of the world. In: Wondwell GM (ed) The role of terrestrial vegetation in the global carbon cycle: measurement by remote sensing. John Wiley \& Sons Ltd, pp 91109. https://catalog.hathitrust.org/Record/000123236

Chave J, Andalo C, Brown S, Cairns MA, Chambers JQ, Eamus D, Fölster H, Fromard F, Higuchi N, Kira T, Lescure J, Nelson B, Ogawa H, Puig H, Riera B, Yamakura T (2005) Tree allometry and improved estimation of carbon stocks and balance in tropical forests. Oecologia 145:87-99. https://doi.org/10.1007/s00442-005$0100-\mathrm{x}$

Chmura GL, Anisfeld SC, Cahoon DR, Lynch JC (2003) Global carbon sequestration in tidal, saline wetland soils. Global Biogeochemical Cycles 17:1111. https://doi.org/10.1029/2002GB001917

Clark B, York R (2005) Carbon metabolism: global capitalism, climate change, and the biospheric rift. Theory and Society 34:391-428. https://doi.org/10.1007/s11186-005-1993-4

Craft CB, Seneca ED, Broome SW (1991) Loss on ignition and Kjeldahl digestion for estimating organic carbon and total nitrogen in estuarine marsh soils: calibration with dry combustion. Estuaries. https:// doi.org/10.2307/1351691

Follett R (2001) Soil management concepts and carbon sequestration in cropland soils. Soil and Tillage Research 61:77-92. https://doi.org/ 10.1016/S0167-1987(01)00180-5

Gorham E (1991) Northern peatlands: role in the carbon cycle and probable responses to climatic warming. Ecological Applications 1:182195. https://doi.org/10.2307/1941811

Hettiarachchi M, Athukorale K, Wijekoon S, de Alwis A (2014) Urban wetlands and disaster resilience of Colombo, Sri Lanka. Int J Disast Resilience Built Environ 5:79-89. https://doi.org/10.1108/IJDRBE11-2011-0042

Hoogsteen MJJ, Lantinga EA, Bakker EJ, Groot JCJ, Tittonell PA (2015) Estimating soil organic carbon through loss on ignition: effects of ignition conditions and structural water loss. European Journal of Soil Science 66:320-328. https://doi.org/10.1111/ejss.12224

Howard PJA, Howard DM (1990) Use of organic carbon and loss-onignition to estimate soil organic matter in different soil types and horizons. Biology and Fertility of Soils 9:306-310. https://doi.org/ 10.1007/BF00634106

IPCC (2002) Climate change and biodiversity. IPCC technical paper V. IPCC, 2007: mitigation of climate change https://www.ipcc.ch/site/ assets/uploads/2018/03/climate-changes-biodiversity\%20en.pdf. Accessed 29 Oct 2020

IPCC (2003) Good practice guidance for land use, land use change and forestry. Institute for Global Environmental Strategies https://www. ipcc.nggip.iges.or.jp/public/gpglulucf/gpglulucf_files/GPG LULUCF FULL.pdf. Accessed 28 Jan 2019

IUCN (2017) Peatlands and climate change https://www.iucn.org/sites/ $\mathrm{dev} /$ files/peatlands and climate change issues brief final.pdf. Accessed 29 Oct $20 \overline{2} 0$

IUCN, CEA (2006) National wetland directory of Sri Lanka. IUCN, Sri Lanka http://www.cea.lk/web/images/pdf/7-1.Book-NationalWetland-Directory-Low\%20res(1).pdf. Accessed 28 Jan 20

Joosten H, Couwenberg J, von Unger M (2016) International carbon policies as a new driver for peatland restoration. In: Bonn A, Allot T, Evans M, Joosten H, Stoneman R (eds) Peatland restoration and ecosystem services: science, policy and practice. Cambridge University Press/British Ecological Society, Cambridge

Kauffman JB, Donato DC (2012) Protocols for the measurement, monitoring and reporting of structure, biomass and carbon stocks in mangrove forests. CIFOR, Bogor. https://doi.org/10.17528/cifor/003749 
Lal R (2004) Soil carbon sequestration to mitigate climate change. Geoderma 123:1-22. https://doi.org/10.1016/j.geoderma.2004.01. 032

Lal R (2008) Carbon sequestration. Philosophical Transactions of the Royal Society B 363:815-830. https://doi.org/10.1098/rstb.2007. 2185

Landva AO, Korpijaakko EO, Pheeney PE (1983) Geotechnical classification of peats and organic soils, in testing of peats and organic soils. ASTM Int. https://doi.org/10.1520/STP37333S

Lucas RE (1982) Organic soils (Histosols) formation, distribution, physical and chemical properties and management for crop production. Research Report 435 Farm Science. https://babel.hathitrust.org/cgi/ pt?id=uiug.30112019633574\&view=1 up\&seq=7

Ma K, Liu J, Zhang Y, Parry L, Holden J, Ciais P (2015) Refining soil organic carbon stock estimates for China's palustrine wetlands. Environmental Research Letters 10:124016

Maltby E, Immirzi P (1993) Carbon dynamics in peatlands and other wetland soils, regional and global perspectives. Chemosphere 27: 999-1023. https://doi.org/10.1016/0045-6535(93)90065-D

MCUDP (2016) Final report of Colombo wetland management startergy. Governement of Sri Lanka https://www.ramsar.org/sites/default/ files/Colombo\%20Wetland\%20Management\%20Strategy.pdf. Accessed 27 Jan 2019

Mielke MS, Matos EM, Couto VB, de Almeida A-AF, Gomes FP, Mangabeira PAO (2005) Some photosynthetic and growth responses of Annona glabra L. seedlings to soil flooding. Acta Botânica Brasílica 19:905-911. https://doi.org/10.1590/S010233062005000400025

Miettinen J, Hooijer A, Vernimmen R, Liew SC, Page SE (2017) From carbon sink to carbon source: extensive peat oxidation in insular Southeast Asia since 1990. Environmental Research Letters 12. https://doi.org/10.1088/1748-9326/aa5b6f

Millennium Ecosystem Assessment (2005) Ecosystems and human wellbeing: wetlands and water synthesis. World Resources Institute, Washington, DC https://www.millenniumassessment.org/ en/index.html. Accessed 29 Oct 2020

Mitsch WJ, Bernal B, Nahlik AM, Mander Ü, Zhang L, Anderson CJ, Jørgensen SE, Brix H (2013) Wetlands, carbon, and climate change. Landscape Ecology 28:583-597. https://doi.org/10.1007/s10980012-9758-8

Murdiyarso D, Kauffman JB, Verchot LV (2013) Climate change mitigation strategies should include tropical wetlands. Carbon Management 4:491-499. https://doi.org/10.4155/cmt.13.46

Paul C, Saras W, Madeline B, Jeff B, Pere M, Kate B, Peter M (2018) Carbon stocks, sequestration, and emissions of wetlands in south eastern Australia. Global Change Biology 24:1-12. https://doi.org/ 10.1111/gcb.14319

Paustian K, Collins HP, Paul EA (1997) Management controls on soil carbon. In: Paul EA, Elliott ET, Paustian K, Cole CV (eds) Soil organic matter in temperate agroecosystems. CRC Press, New York, pp 15-49

Perera KARS, Amarasinghe MD (2019) Carbon sequestration capacity of mangrove soils in micro tidal estuaries and lagoons: a case study from Sri Lanka. Geoderma 347:80-89. https://doi.org/10.1016/j. geoderma.2019.03.041

Powlson DS, Whitmore AP, Goulding KWT (2011) Soil carbon sequestration to mitigate climate change: a critical re-examination to identify the true and the false. European Journal of Soil Science 62:42 55. https://doi.org/10.1111/j.1365-2389.2010.01342.x

Pribyl DW (2010) A critical review of the conventional SOC to SOM conversion factor. Geoderma 156:75-83. https://doi.org/10.1016/j. geoderma.2010.02.003

Saunders MJ, Jones MB, Kansiime F (2007) Carbon and water cycles in tropical papyrus wetlands. Wetlands Ecology and Management 15: 489-498. https://doi.org/10.1007/s11273-007-9051-9.1

Sebastian R, Chacko J (2006) Distribution of organic carbon in tropical mangrove sediments (Cochin, India). International Journal of Environmental Studies 63:303-311. https://doi.org/10.1080/ 00207230600720498

Stern J, Wang Y, Gu B, Newman J (2007) Distribution and turnover of carbon in natural and constructed wetlands in the Florida Everglades. Applied Geochemistry 22:1936-1948. https://doi.org/ 10.1016/j.apgeochem.2007.04.007

STRP (2009) Wetlands and the UNFCCC COP15 climate change meeting (Copenhagen, 7-18, December 2009) https://www.ramsar.org/ sites/default/files/documents/pdf/strp/strp briefing climate 2009 e.pdf. Accessed 29 Oct 2020

Tomlinson RW, Davidson L (2000) Estimates of carbon stores in four northern Irish lowland raised bogs. Suo 51:169-179

UNFCCC (2017) United Nations framework convention on climate change, Paris agreement-status of ratification http://unfccc.int/ paris_agreement/items/9444.php. Accessed 29 Oct 2020

USDA (2014) Keys to soil taxonomy. Natural Resources Conservation Services, United States Department of Agriculture, Washington DC https://www.nrcs.usda.gov/wps/portal/nrcs/detail/soils/survey/class/ taxonomy/?cid=nrcs142p2_053580. Acessed 25 January 2019

WB, GFDRR (2018) Urban wetlands management in Colombo: a new model for urban resilience https://reliefweb.int/report/sri-lanka/ urban-wetlands-management-colombo-new-model-urbanresilience. Accessed 10 Oct 2019

Were D, Kansiime F, Fetahi T, Cooper A, Jjuuko C (2019) Carbon sequestration by wetlands: a critical review of enhancement measures for climate change mitigation. Earth Syst Environ 3:327-340. https://doi.org/10.1007/s41748-019-00094-0

Whiting GJ, Chanton JP (2001) Greenhouse carbon balance of wetlands: methane emission versus carbon sequestration. Tellus, Series B 53: 521-528. https://doi.org/10.3402/tellusb.v53i5.16628

Zotz G, Tyree MT, Patiño S (1997) Hydraulic architecture and water relations of a flood-tolerant tropical tree, Annona glabra. Tree Physiology 17:359-365. https://doi.org/10.1093/treephys/17.6.359

Publisher's Note Springer Nature remains neutral with regard to jurisdictional claims in published maps and institutional affiliations. 